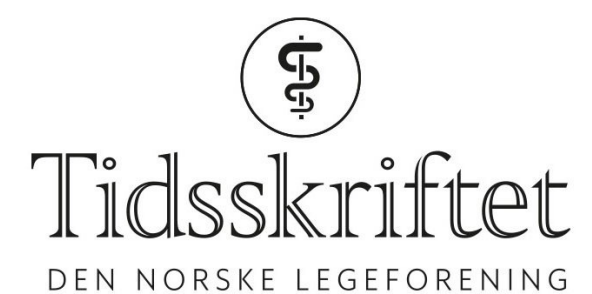

DEN NORSKE LEGEFORENING

\title{
Ny klassifikasjon av epileptiske anfall
}

DEBATT

\section{OLIVER HENNING}

E-post: oliver.henning@ous-hf.no Oliver Henning (f. 1965) er spesialist i nevrologi og i psykiatri og overlege ved Avdeling for kompleks epilepsi, Spesialsykehuset for epilepsi, Oslo universitetssykehus. Han har lang erfaring innen epilepsi og er leder av Norsk Epilepsiselskap.

Forfatter har fylt ut ICMJE-skjemaet og oppgir ingen interessekonflikter.

\section{KARL O. NAKKEN}

Karl O. Nakken (f. 1945) er dr.med., spesialist i nevrologi og overlege ved Avdeling for kompleks epilepsi, Spesialsykehuset for epilepsi, Oslo universitetssykehus. Han har spesialkompetanse på epilepsisykdommer og er æresmedlem i Norsk Epilepsiselskap.

Forfatter har fylt ut ICMJE-skjemaet og oppgir ingen interessekonflikter.

En ny modell for klassifisering av epileptiske anfall bygger hovedsakelig på hvordan anfallene ytrer seg klinisk. Riktig klassifisering gir riktig behandling.

Innen epilepsifeltet har det lenge vært enighet om at anfallsklassifikasjonen fra 1981 har gått ut på dato. International League Against Epilepsy (ILAE) startet derfor i 2010 arbeidet med en ny anfallsklassifikasjon. Etter en langvarig og vanskelig prosess er nå endelig en ny klassifikasjon vedtatt. Den ble publisert i april i år 2017 (1-3).

Den nye klassifikasjonen er hovedsakelig en semiologisk klassifikasjon. Det betyr at anfallene inndeles etter hvordan de ytrer seg klinisk. Klassifikasjon på bakgrunn av bakenforliggende patofysiologiske mekanismer er foreløpig ikke mulig. Kunnskapen strekker ikke til.

Selv om det i dag er enighet om at det ofte er uskarpe grenser mellom fokale og generaliserte anfall, har man valgt å beholde den gamle dikotomien, blant annet av didaktiske grunner.

Norsk Epilepsiselskap (NES) er den norske grenen av International League Against Epilepsy. Vi har nå oversatt den nye anfallsklassifikasjonen til norsk for å implementere den i epilepsiomsorgen i Norge (fig 1 ). Vi laget et utkast og sendte det til høring til over 50 fagpersoner ved alle nevrologiske avdelinger, landets epilepsisykepleiere og pasientforeningen. I den følgende presentasjonen har vi tatt hensyn til mange av innspillene vi har fått underveis. 


\begin{tabular}{|c|c|c|c|}
\hline \multicolumn{2}{|c|}{ Fokal anfallsstart } & Generalisert anfallsstart & Ukjent anfallsstart \\
\hline $\begin{array}{l}\text { Bevart } \\
\text { bevissthet }\end{array}$ & $\begin{array}{l}\text { Redusert } \\
\text { bevissthet }\end{array}$ & $\begin{array}{l}\text { Motorisk } \\
\text { Tonisk-klonisk }\end{array}$ & $\begin{array}{l}\text { Motorisk } \\
\text { Tonisk-klonisk }\end{array}$ \\
\hline $\begin{array}{r}\text { Motorisk } \\
\text { Automa } \\
\text { Atonisk }\end{array}$ & eer & $\begin{array}{l}\text { Tonisk } \\
\text { Myoklonisk } \\
\text { Myoklonisk-tonisk-klonisk }\end{array}$ & $\begin{array}{l}\text { Ikke-motorisk } \\
\text { Atferdsstans }\end{array}$ \\
\hline \multicolumn{2}{|c|}{ Klonisk } & Myoklonisk-atonisk & \\
\hline \multicolumn{2}{|c|}{ Epileptiske spasmer } & Atonisk & Uklassifisert \\
\hline \multicolumn{2}{|c|}{ Hypermotorisk } & Epileptiske spasmer & \\
\hline \multicolumn{2}{|c|}{ Myoklonisk } & Ikke-motorisk(absenser) & \\
\hline \multicolumn{2}{|c|}{ Tonisk } & Typisk & \\
\hline \multicolumn{2}{|c|}{ Ikke-motorisk } & Atypisk & \\
\hline \multicolumn{2}{|c|}{ Autonom } & Myoklonisk & \\
\hline \multicolumn{2}{|c|}{ Atferdsstans } & Øyelokksmyoklonier & \\
\hline \multicolumn{2}{|c|}{ Emosjonell } & & \\
\hline \multicolumn{2}{|c|}{ Sensorisk } & & \\
\hline \multicolumn{2}{|c|}{$\begin{array}{l}\text { Fokal tilbilateral } \\
\text { tonisk-klonisk }\end{array}$} & & \\
\hline
\end{tabular}

Figur 1 Anfallsklassifikasjon på norsk. Omarbeidet etter engelsk versjon (1), med tillatelse

\section{Bruk av den nye anfallsklassifikasjonen}

\section{ANFALLSSTART}

Hvordan anfallet startet, er det første klinikeren må ta stilling til (ramme 1). Har anfallet motoriske elementer? Hvis ja, er disse fokale (for eksempel hodevridning til en side) eller generaliserte? Dersom anfallet startet med for eksempel en rar lukt eller en déjà vufornemmelse, taler det for et fokalt, ikke-motorisk anfall. Det betyr anfallsstart i et nevronalt nettverk begrenset til den ene hemisfæren.

Starter anfallet med for eksempel korte bilaterale rykninger, taler det for et generalisert anfall, dvs. anfall som oppstår i og raskt involverer bihemisfæriske cellenettverk.

Det anbefales å klassifisere et anfall som fokalt eller generalisert når det er en høy grad av sikkerhet bak klassifikasjonen. Hvis anfallsstarten ikke er kjent, klassifiseres anfallet som anfall med ukjent start.

RAMME 1 HVORDAN KLASSIFISERE ET ANFALL?

1 Avgjør først om anfallsstarten er fokal eller generalisert, eventuelt ukjent 2 Hvis det er et fokalt anfall, vurder om grad av bevissthet kan bestemmes. Det kan eventuelt utelates

3 Avgjør om anfallet har motoriske elementer eller ikke. Et fokalt anfall med bevart eller redusert bevissthet kan videre klassifiseres etter motoriske eller ikke-motoriske symptomer 4 Anfall som har opphør av aktivitet eller atferd som det mest fremtredende trekk, klassifiseres som anfall med atferdsstans 5 Begreper som «motorisk» eller «ikke-motorisk» kan utelates dersom anfallstypen ellers er entydig definert. Eksempel: fokalt hypermotorisk anfall

6 I tillegg til anfallsklassifikasjonen oppfordres det til å beskrive anfallssemiologien så godt som mulig. Eksempel: fokalt emosjonelt anfall med tilstivning i høyre arm og takykardi 7 Bruk begrepet «bilateralt tonisk-klonisk anfall» dersom krampeanfallet starter fokalt, og "generalisert tonisk-klonisk anfall» dersom krampeanfallet tilsynelatende oppstår samtidig i begge hemisfærer

Ved subklassifisering av fokale anfall bør vurdering av bevissthetsnivået inkluderes. 
Benyttes «fokalt anfall med bevart bevissthet», det som før kaltes «enkle partielle anfall», skal det være bevart bevissthet under hele anfallsforløpet. International League Against Epilepsy definerer bevissthet som «kunnskap eller forståelse om seg selv og omgivelsene». I praksis betyr bevart bevissthet at personen etter anfallet kan huske og formidle det som skjedde underveis, selv om personen eventuelt ikke kunne bevege seg. Dersom bevisstheten er redusert under en del av anfallet, klassifiseres det som anfall med redusert bevissthet (det som før kaltes «komplekse partielle anfall»).

Dersom graden av bevissthet er ukjent, utelates slik subklassifisering og man nøyer seg eventuelt med å klassifisere anfallet som fokalt.

\section{MOTORISK OG IKKE-MOTORISK ANFALLSSTART}

Fokale anfall er videre inndelt i anfall med motoriske eller ikke-motoriske symptomer. Hvis det forekommer både motoriske og ikke-motoriske symptomer, vil de første anfallssymptomene være avgjørende. For eksempel, dersom anfallet starter i form av epigastrisk aura, og så etterfølges av automatismer, klassifiseres det som et fokalt anfall med ikke-motoriske symptomer.

Begrepene «motorisk» og «ikke-motorisk» kan utelates dersom det dreier seg om en veldefinert anfallstype som for eksempel et fokalt klonisk anfall.

\section{ANFALL MED KOGNITIVE SYMPTOMER}

Begrepet «psykisk» er nå erstattet av «kognitiv» og refererer til spesifikke kognitive fenomener under anfall, for eksempel afasi, apraksi eller neglekt. Kognitive anfall kan også omfatte fenomener som déjà vu, jamais vu, illusjoner eller hallusinasjoner.

\section{ANFALL MED EMOSJONELLE SYMPTOMER}

Et fokalt ikke-motorisk anfall kan ha emosjonelle symptomer som frykt eller glede, men også affektive symptomer som mangler subjektiv emosjonalitet, som gelastiske eller dakrystiske anfall - dvs. med henholdsvis latter eller gråt.

\section{BILATERALE TONISK-KLONISKE ANFALL MED FOKAL START}

«Fokalt anfall med utvikling til bilateralt tonisk-klonisk anfall» beskriver et spredningsmønster. Det erstatter det tidligere begrepet «sekundært generalisert toniskklonisk anfall». I den nye klassifiseringen er begrepet "generalisert» reservert for anfall med generalisert start, dvs. det som tidligere ble kalt "primært generalisert anfall». Begrepet «bilateral» brukes følgelig om tonisk-kloniske anfall som starter fokalt i den ene hemisfæren, og "generalisert» for anfall som tilsynelatende oppstår samtidig i begge hemisfærer.

\section{UKLASSIFISERTE ANFALL}

Kategoriseringen «uklassifisert» bør kun brukes unntaksvis når klinikeren er overbevist om at det var et epileptisk anfall, men opplysningene er for sparsomme til å kunne klassifisere nærmere.

Klassifiseringsdiagrammet er gruppert, men ikke hierarkisk oppbygd. Det betyr at enkelte nivåer kan utelates når man beskriver anfallet.

\section{Vi må snakke samme språk}

I all klinisk virksomhet, kunnskapsformidling og forskning innen epilepsi er det viktig at vi snakker samme språk (ramme 2). Vi håper at den nye anfallsklassifikasjonen raskt blir tatt $\mathrm{i}$ bruk av alle som er involvert i omsorgen for epilepsipasienter i Norge. 


\section{Ramme 2 Forkortelser}

Vi foreslår at følgende forkortelser blir brukt:

$\mathrm{FB}=$ fokalt anfall med bevart bevissthet (tidligere EPA)

$\mathrm{FR}=$ fokalt anfall med redusert bevissthet (tidligere KPA)

GTK = generalisert tonisk-klonisk anfall (tidligere primært generalisert tonisk-klonisk anfall)

FTK = fokalt anfall med utvikling til et bilateralt tonisk-klonisk anfall (tidligere sekundært generalisert tonisk-klonisk anfall)

\section{LITTERATUR:}

1. Fisher RS, Cross JH, French JA et al. Operational classification of seizure types by the International League Against Epilepsy: Position Paper of the ILAE Commission for Classification and Terminology. Epilepsia 2017; 58: 522 - 30. [PubMed][CrossRef]

2. Fisher RS, Cross JH, D'Souza C et al. Instruction manual for the ILAE 2017 operational classification of seizure types. Epilepsia 2017; 58: 531 - 42. [PubMed][CrossRef]

3. Fisher RS. An overview of the 2017 ILAE operational classification of seizure types. Epilepsy Behav 2017; 70: 271 - 3. [PubMed][CrossRef]

Publisert: 13. november 2017. Tidsskr Nor Legeforen. DOI:10.4045/tidsskr.17.0894

Mottatt 16.10.2017, godkjent 20.10.2017.

(C) Tidsskrift for Den norske legeforening 2020. Lastet ned fra tidsskriftet.no 